\title{
アルカリ土類修飾による石炭液化油水素化処理 モリブデン触媒上への炭素質たい積の制御
}

\author{
島田 広道 ${ }^{\dagger 1)}$, 佐藤 利夫 ${ }^{+1)}$, 臀村 雄二十1), 西嶋 昭生 $^{\dagger 1}{ }^{*}$

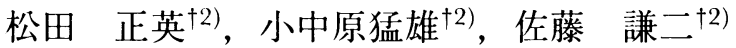 \\ †1)化学技術研究所, 305 茨城県つくば市東 1-1 \\ †2) 東京理科大学理工学部工業化学科, 278 千葉県野田市山崎東亀山
}

(昭和 62 年 8 月 26 日受理)

\begin{abstract}
液化油の水素化処理中に起こる触媒上への炭素質析出防止対策としてアルカリ土類修飾による触媒の酸性質制御を 試みた。修飾触媒では炭素質たい積抑制の効果は認められたが液化油の水素化脱窒素活性は低下した。修飾効果は原 料油によって異なり，アスファルテンを含む重質油の場合，Mg 修飾が炭素質たい積の抑制に有効でありかつ活性低 下が少なかった。Ca 修飾は酸性質制御の効果は大きいが触媒基本活性の低下も大きいため，炭素質たい積の抑制に は有効である一方，液化油脱窒素活性の低下は大きかった。Ca 修飾触媒では，たい積炭素質のコーク化が進行して おり、コーク析出の抑制には酸性質制御と同時に水素化活性を賦与することも重要であると推察された。
\end{abstract}

\section{1. 緒言}

重質炭化水素資源の水素化処理プロセスでは反応中に起こる 触媒上への炭素質の析出が触媒活性を著しく低下させることが 知られている。特に, 石炭系の原料では石油系の原料に比べて, $\mathrm{H} / \mathrm{C}$ 比（炭素水素原子比）が小さいこと, 窒素, 酸素などの 極性成分を多く含むことなどから, 炭素質析出が起こりやすく, 触媒寿命も短くなることが予想されており ${ }^{1)-5)}$ ，より経済的 な石炭液化プロセスの設計にあたっては上記被毒作用を防ぎ触 媒活性低下を抑制する手法の確立が必要となっている。

炭素質による触媒の活性低下は, 反応の初期段階では, 触媒 表面への極性物質の吸着による活性点の一時的被覆, および細 孔拡散の阻害による。続いて, 強吸着された炭素質の重合によ り不活性コーク質が形成され, 活性点の永久被毒, 細孔の閉そ くを引き起こして触媒を失活させる。昼－10)このような活性低 下機構を考慮すれば，炭素質による触媒活性低下の抑制には， 極性物質等の強吸着を防ぎ, さらに吸着炭素質のコーク化を防 止することが必要と推察される。

触媒の固体酸点は, 石炭液化油中に多く含まれる極性物質の 強吸着点となりやすく ${ }^{11}$, また, 接触分解触媒などの例にみ られるように強酸点上では脱水素, 重合反応によるコーク析出 が起こりやすい。従って, 上記活性低下の抑制にあたっては, 触媒酸性質の制御, 改質は, もっとも重要な検討課題の一つと 考えられるが, 一方, 固体酸点は水素化分解反応などの触媒活 性点として作用することから ${ }^{12)}$, 酸性質の制御は同時に触媒 活性の低下をもたらすことも予想される。

本研究では, この様な観点からアルカリ土類酸化物修飾によ る触媒酸性質の制御を行い, 炭素質のたい積を抑制することを 試みた。また，モデルテスト反応を用いての触媒活性の検討な どにより，アルカリ土類修飾が触媒の基本機能におよほす影響

* 連絡先
を検討した。さらに，上記結果を考え併せ，触媒の酸性質，基 本機能と触媒上への炭素質のたい積挙動との相関について議論 した。

\section{2. 実 \\ $2 \cdot 1$ 触媒調製}

モリブデン触媒 $\left(\mathrm{MoO}_{3}\right.$ として $10 \mathrm{wt} \%$ 担持 $)$ は, $\gamma$-アル ミナ担体 (表面積 : $210 \mathrm{~m}^{2} / \mathrm{g}$, 細孔容積 : $0.71 \mathrm{ml} / \mathrm{g}$ ) にパラモ リブデン酸アンモニゥム水溶液を含浸させた後, $100^{\circ} \mathrm{C}(24$ 時 間), $300^{\circ} \mathrm{C}$ (3 時間), $500^{\circ} \mathrm{C}$ (3 時間) で乾燥, 焼成を行うこと

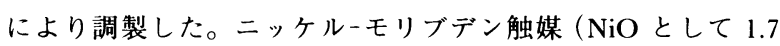
$\mathrm{wt} \%, \mathrm{MoO}_{3}$ として $6.7 \mathrm{wt} \%$ 担持) では含浸水溶液として硝 酸ニッケル，パラモリブデン酸アンモニウムの混合水溶液を用 いた。 Mg, Ca の修飾はそれぞれ硝酸マグネシウム, 硝酸カル シウム水溶液を用いて行った。修飾方法としては以下の三方法 について検討した。

A : $\gamma$-アルミナ担体をまず, $\mathrm{Mg}$, あるいは $\mathrm{Ca}$ で修飾 (含浸, 乾燥, 焼成) した後, 活性成分 $(\mathrm{Mo}, \mathrm{Ni}-\mathrm{Mo}$ ) を担持する。

$\mathrm{B}$ : 担体を活性成分水溶液に含浸後, 引続き $\mathrm{Mg}$, あるいは $\mathrm{Ca}$ の水溶液に含浸し, 乾燥, 焼成する。

$\mathrm{C}:$ 焼成後の, Mo, Ni-Mo 触媒を Mg, Ca 水溶液に含浸し乾 燥, 焼成する。

全ての触媒は，モデルテスト反応，液化油の水素化反応に先 立って $5 \mathrm{vol} \% \mathrm{H}_{2} \mathrm{~S} / \mathrm{H}_{2}$ 気流中で $400^{\circ} \mathrm{C}, 1$ 時間, 予備硫化した。

\section{$2 \cdot 2$ 液化油の水亲化処理反応}

本研究では水素化処理反応の原料油として, ワンドアン炭を 原料とする液化油中質留分 (以下, 液化油 A), および重質留 分（同，B， C）を用いた。各液化油の性質は Table 1 に示した。 水素化処理反応には, 内容積 $50 \mathrm{ml}$ の急速昇温式（室温〜 $400^{\circ} \mathrm{C}$ まで約 5 分）バッチ式オートクレーブを用いた。反応 は液化油 $10 \mathrm{~g}$, 触媒 $0.5 \mathrm{~g}$ を反応器に仕込み, 水素初圧 14.7 $\mathrm{MPa}$, 反応温度 $425^{\circ} \mathrm{C}$, 時間 2 時間の条件で行った。反応終 
Table 1 Properties of Feedstocks

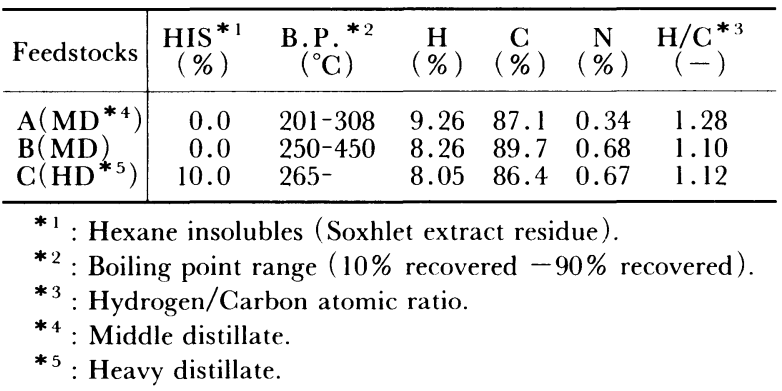

了後, 液状成分中の窒素分を電量滴定法 (三菱化成 : 全窒素分 析計, TN-2）により定量し, 脱窒素率を用いて触媒の水素化 処理活性を評価した。使用済み触媒はへキサン，あるいはトル エンを用いてソックスレー抽出法により洗浄した後, たい積炭 素質の量を元素分析計（柳本製作所，CHN コーダー， MT-3） により定量した。

\section{$2 \cdot 3$ 蝶のキャラクタリゼーション}

試作した触媒の表面積は, BET 法 (Carlo Erba： Sorptomatic）により求めた。触媒の基本活性である, 水素化 (HY), 水素化分解 (HC) 活性について, バッチ式オートクレー ブを用いた水素高圧下のモデルテスト反応により評価した。 HY 活性の評価には, 1-メチルナフタレン（1-MN）の水素化反 応によって得られる1-抢よび5-メチルテトラリンの収率を, HC 活性の評価には, ジフェニルメタン (DPM) の水素化分解 反応によって得られるトルエンおよびベンゼンの収率を用い た。反応は, 原料成分 $10 \mathrm{ml}$, 触媒 $0.5 \mathrm{~g}$ を反応器に仕込み, 温度 $350-400^{\circ} \mathrm{C}, 1$ 時間の条件で行った。生成物はガスクロマ トグラフにより分析した。

触媒の酸性質は，熱天科（島津製作所：TG-30）を用いたア ンモニアの昇温脱離（TPD）法によって評価した。窒素気流中， $500^{\circ} \mathrm{C}$ で予備処理した試料に $2 \mathrm{vol} \% \mathrm{NH}_{3} / \mathrm{N}_{2}$ を用いて $150^{\circ} \mathrm{C}$ で $\mathrm{NH}_{3}$ を吸着させ飽和量に達した後, 窒素気流中で余分の $\mathrm{NH}_{3}$ をパージし, 昇温 $\left(10^{\circ} \mathrm{C} / \mathrm{min}\right)$ スペクトルを得た。低温 域で脱離したアンモニアは酸点に吸着したものとは考えにく (13)ことから, 得られたスペクトルをもとに $300^{\circ} \mathrm{C}$ 以上での アンモニア脱離量を計算し酸量とした。

\section{3. 結果と考察}

\section{$3 \cdot 1$ 徏飾方法が触媒基本活性に及ぼす影翌}

液化油の水素化处理反応を行う前に, 適当と思われるアルカ リ土類修飾法を選択するため, モデルテスト反応を行って触媒 の基本活性を評価した。2・1 に示した三通りの修飾法により 調製した $2 \mathrm{wt} \% \mathrm{CaO}-10 \mathrm{wt} \% \mathrm{MoO}_{3} / \mathrm{Al}_{2} \mathrm{O}_{3}$ 触媒の $\mathrm{HY}, \mathrm{HC}$ 活 性を測定した結果を Table 2 に示した。いずれの方法でも, HC 活性のみでなく, HY 活性も低下しており, アルカリ土類 修飾は触媒の酸性質を制御するのみでなく水素化活性点を被毒 していることがわかる。

各修飾法を比較すると, B 法, A 法, C 法の順に活性低下 の度合は大きい。修飾による活性低下原因は後述 $(\mathbf{3} \cdot \mathbf{3})$ する ように，主に $\mathrm{CaMoO}_{4}$ 粒子の生成による活性金属有効表面積 の滅少および活性金属の化学結合状態の変化と考えられる。修
Table 2 Effect of Preparation Procedure on Fundamental Activities of $2 \% \mathrm{Ca}$-Doped Mo Catalyst

\begin{tabular}{c|cc}
\hline Catalyst & \multicolumn{1}{|c}{$\mathrm{HY}^{* 1}$} & $\mathrm{HC}^{* 2}$ \\
\hline $\mathrm{Mo} / \mathrm{Al}_{2} \mathrm{O}_{3}$ & $33.2(1.00)$ & $6.7(1.00)$ \\
$\mathrm{Ca}-\mathrm{Mo} / \mathrm{Al}_{2} \mathrm{O}_{3}(\mathrm{~A})^{* 3}$ & $15.0(0.45)$ & $3.9(0.58)$ \\
$\mathrm{Ca}-\mathrm{Mo} / \mathrm{Al}_{2} \mathrm{O}_{3}(\mathrm{~B})^{* 4}$ & $7.5(0.23)$ & $2.4(0.36)$ \\
$\mathrm{Ca}-\mathrm{Mo} / \mathrm{Al}_{2} \mathrm{O}_{3}(\mathrm{C})^{* 5}$ & $25.3(0.76)$ & $4.0(0.60)$ \\
\hline
\end{tabular}

${ }^{*}$ : Hydrogenation activity. Figures show yields of methyltetralins (\%) from 1-methylnaphthalene. Figures in parentheses show the relative activity to the catalyst without $\mathrm{Ca}$ additive.

${ }^{*} 2$ : Hydrocracking activity. Figures show yields of benzene and toluene (\%) from diphenylmethane. Figures in parentheses show the relative activity to the catalyst without $\mathrm{Ca}$ additive.

${ }^{*} 3$ : Catalyst with $2 \%$ of $\mathrm{CaO}$. $\mathrm{CaO}$ was impregnated on the $\mathrm{Al}_{2} \mathrm{O}_{3}$ before the impregnation of $\mathrm{MoO}_{3}$.

${ }^{*}$ : Catalyst with $2 \%$ of $\mathrm{CaO}$. $\mathrm{CaO}$ and $\mathrm{MoO}_{3}$ was impregnated at the same time on the $\mathrm{Al}_{2} \mathrm{O}_{3}$.

* 5 : Catalyst with $2 \%$ of $\mathrm{CaO}$. $\mathrm{CaO}$ was impregnated on the $\mathrm{Al}_{2} \mathrm{O}_{3}$ after the impregnation of $\mathrm{MoO}_{3}$.

Table 3 Nitrogen Removal and Carbonaceous Deposition on $\mathrm{Ca}(\mathrm{Mg})$-Doped $\mathrm{Mo} / \mathrm{Al}_{2} \mathrm{O}_{3}$ Catalysts Used for Hydrotreating Coal-Derived Liquids

\begin{tabular}{l|rrrr}
\hline \multicolumn{1}{c|}{ Catalyst } & \multicolumn{2}{c}{ Feed } & $\mathrm{A}$ & \multicolumn{2}{c}{ Feed } & $\mathrm{C}$ \\
\hline & $\begin{array}{r}\mathrm{DN} \\
(\%)^{* 1}\end{array}$ & $\begin{array}{c}\mathrm{C} . \mathrm{Dep}_{2} \\
(\%)\end{array}$ & $\begin{array}{c}\mathrm{DN} \\
(\%)\end{array}$ & $\begin{array}{c}\text { C.Dep. } \\
(\%)\end{array}$ \\
\hline $\mathrm{Mo} / \mathrm{Al}_{2} \mathrm{O}_{3}$ & 26.3 & 4.5 & 8.9 & 10.8 \\
$2 \% \mathrm{CaO}-\mathrm{Mo} / \mathrm{Al}_{2} \mathrm{O}_{3}$ & 13.4 & 4.4 & 0.0 & 9.2 \\
$5 \% \mathrm{CaO}-\mathrm{Mo} / \mathrm{Al}_{2} \mathrm{O}_{3}$ & 9.8 & 4.4 & 0.0 & 14.8 \\
$2 \% \mathrm{MgO}-\mathrm{Mo} / \mathrm{Al}_{2} \mathrm{O}_{3}$ & 19.1 & 4.2 & 0.1 & 7.6 \\
$5 \% \mathrm{MgO}-\mathrm{Mo} / \mathrm{Al}_{2} \mathrm{O}_{3}$ & 13.0 & 4.2 & 0.0 & 8.1 \\
\hline
\end{tabular}

${ }^{* 1}$ : Nitrogen removal.

*2 : Carbonaceous deposition (Hexane insoluble materials).

飾方法による活性低下の序列についても，上記 $\mathrm{CaMoO}_{4}$ の成 長の程度が異なることに起因すると考察される。以下の実験で は活性低下の最も少なかった C 法によりアルカリ土類修飾し た触媒を試料として用いた。

\section{$3 \cdot 2$ 液化油の水秦化処理反応}

\section{$3 \cdot 2 \cdot 1$ モリブデン触媒}

$2 \%, 5 \%$ の $\mathrm{CaO}, \mathrm{MgO}$ 修飾モリブデン触媒を用いたときの 液化油の脱窒素率を Table 3 に示した。アルカリ土類修飾し た触媒では， $\mathrm{Mg}, \mathrm{Ca}$ いずれの場合も脱窒素活性が低下してい ること，また $5 \%$ 修飾した触媒では $2 \%$ 修飾した触媒よりも 活性低下が大きいことがわかる。特にへキサン不溶分を含む液 化油 $\mathrm{C}$ の場合, アルカリ土類修飾触媒では脱窒素反応の進行 がほとんど認められず, 脱窒素反応の進行を図るためには修飾 は好ましくないことを示している。 Mg 修飾触媒と Ca 修飾触 媒との活性を比較すると, いずれの場合も $\mathrm{Mg}$ 修飾の方が活 性低下の程度は小さかった。

各反応に使用した触媒上にたい積した炭素質量（へキサン不 溶分）を定量した結果を Table 3 に併せて示した。重質成分 を含まない液化油 A の場合, 炭素質たい積量は触媒によらず ほぼ一定であった。これは, 液化油 A では触媒に強吸着され ヘキサン不溶になる成分が少なく，炭素質のたい積におよほす 
Table 4 Nitrogen Removal and Carbonaceous Deposition on $\mathrm{Ca}(\mathrm{Mg})$-Doped $\mathrm{Ni}-\mathrm{Mo} / \mathrm{Al}_{2} \mathrm{O}_{3}$ Catalysts Used for Hydrotreating Coal-Derived Liquids

\begin{tabular}{|c|c|c|c|c|c|c|}
\hline \multirow[t]{2}{*}{ Catalyst } & \multicolumn{2}{|c|}{ Feed A } & \multicolumn{2}{|c|}{ Feed B } & \multicolumn{2}{|c|}{ Feed C } \\
\hline & $\mathrm{DN}^{* 1}$ & C.Dep. ${ }^{* 2}$ & DN & C.Dep. & DN & C.Dep. \\
\hline $\mathrm{Ni}-\mathrm{Mo} / \mathrm{Al}_{2} \mathrm{O}_{3}$ & 45.0 & 4.6 & 40.2 & 10.2 & 33.9 & 12.3 \\
\hline $2 \% \mathrm{CaO}-\mathrm{NiMo} / \mathrm{Al}_{2} \mathrm{O}_{3}$ & 29.1 & 3.8 & 29.5 & 8.2 & 7.7 & 7.1 \\
\hline $5 \% \mathrm{CaO}-\mathrm{NiMo} / \mathrm{Al}_{2} \mathrm{O}_{3}$ & 21.4 & 3.5 & 4.3 & 4.4 & 5.9 & 8.3 \\
\hline $2 \% \mathrm{MgO}-\mathrm{NiMo} / \mathrm{Al}_{2} \mathrm{O}_{3}$ & 20.0 & 4.3 & 30.0 & 8.6 & 33.5 & 10.0 \\
\hline $5 \% \mathrm{MgO}-\mathrm{NiMo} / \mathrm{Al}_{2} \mathrm{O}_{3}$ & 18.6 & 3.8 & 28.4 & 5.6 & 31.5 & 7.4 \\
\hline
\end{tabular}

$*^{* 1}$ : Nitrogen removal.

$*_{2}$ : Carbonaceous deposition (Hexane insoluble materials).

触媒表面の性質の影響が小さいためと考察される。一方, 重質 成分が含まれる液化油 $\mathrm{C}$ では液化油 $\mathrm{A}$ と比べて炭素質たい積 量が多く，たい積炭素質による触媒被毒効果も大きいことがわ かる。触媒間の比較を行うと， $5 \% \mathrm{Ca}$ 修飾の場合を除き，ア ルカリ土類修飾による炭素質たい積量の減少が認められてお り, 修飾触媒では酸性質制御の結果極性成分の強吸着が抑制さ れたことが考察される。

\section{$3 \cdot 2 \cdot 2$ ニッケル-モリブデン触媒}

$\mathrm{Ca}, \mathrm{Mg}$ 修飾したニッケルーモリブデン触媒の液化油脱窒素 活性, および水素化処理反応中の触媒上へのたい積炭素質量を Table 4 に示した。本研究での条件下では, もっとも活性の 高かった無修飾のニッケルーモリブデン触媒でも, 蒸留曲線に 顕著に表れるような軽質化は進行していない。また, 水素消費 量はほほ脱窒素率と比例していることから, 触媒の水素化処理 機能を総合的に示す指標として脱窒素率を選んだ。触媒の脱窒 素活性は, 原料液化油が A, B , C と重質化するに従って低下す る傾向が認められた。この傾向はモリブデン触媒の場合 (Table 3) も認められており, 重質成分中の含窒素成分ほど 脱窒素されにくいこと，また触媒活性が重質成分の吸着により 低下していること年,15) を示している。

アルカリ土類修飾による触媒活性の低下挙動は原料油によっ て異なり, 液化油 $\mathrm{A}$ の場合は $\mathrm{Ca}$ 修飾の方が低下が小さいが, 液化油 $\mathrm{B}, \mathrm{C}$ の場合は $\mathrm{Mg}$ 修飾の方が低下が小さい。特に, へ キサン不溶分を含む液化油 $\mathrm{C}$ の場合, $\mathrm{Ca}$ 修飾触媒では活性低 下が大きいのに対して, Mg 修飾触媒では活性低下が極めて小 さい。修飾量については, 全ての場合について 5\% 修飾触媒 の方が $2 \%$ 修飾触媒より活性低下が著しく, 脱空素活性の低 下を考慮した場合, 過度の量の修飾は好ましくないと考えられ る。また，モリブデン触媒（Table 3) と比較すると, ニッケ ルーモリブデン触媒の方が修飾による脱窒素活性（液化油 $\mathrm{C}$ ) の低下は小さく，原料油が重質成分を含む場合は特に修飾の対 象としてニッケルーモリブデン触媒が好ましいと考えられる。

液化油 A の水素化処理に用いた触媒上への炭素質たい積量 （Table 4) はモリブデン担持触媒の場合と同様アルカリ土類 修飾の有無によらず約 $4 \%$ であった。一方, 液化油 B, C の場 合は, 修飾により炭素質たい積量が隇少しており, 酸性質制御 によるたい積抑制の効果が認められている。Ca 修飾と Mg 修 飾を比較した場合, Ca 修飾触媒の方がたい積炭素質量は少な く酸性質制御の効果が大きいと考えられる。

以上, アルカリ土類修飾触媒を用いて液化油の水素化処理反 応を行い以下のような結果が得られた。
Table 5 Fundamental Activities of $\mathrm{Ca}(\mathrm{Mg})$-Doped Mo and $\mathrm{Ni}$-Mo Catalysts

\begin{tabular}{c|cc}
\hline Catalyst & $\mathrm{HY}^{* 1}(\%)$ & $\mathrm{HC}^{* 2}(\%)$ \\
\hline $\mathrm{Mo} / \mathrm{Al}_{2} \mathrm{O}_{3}$ & $33.2(1.00)$ & $6.7(1.00)$ \\
$2 \% \mathrm{CaO}-\mathrm{Mo} / \mathrm{Al}_{2} \mathrm{O}_{3}$ & $25.3(0.76)$ & $4.0(0.60)$ \\
$5 \% \mathrm{CaO}-\mathrm{Mo} / \mathrm{Al}_{2} \mathrm{O}_{3}$ & $10.0(0.30)$ & $3.2(0.48)$ \\
$2 \% \mathrm{MgO}-\mathrm{Mo} / \mathrm{Al}_{2} \mathrm{O}_{3}$ & $27.5(0.83)$ & $7.4(1.10)$ \\
$5 \% \mathrm{MgO}-\mathrm{Mo} / \mathrm{Al}_{2} \mathrm{O}_{3}$ & $27.4(0.83)$ & $6.1(0.91)$ \\
& & \\
$\mathrm{Ni}-\mathrm{Mo} / \mathrm{Al}_{2} \mathrm{O}_{3}$ & $53.7(1.00)$ & $4.4(1.00)$ \\
$2 \% \mathrm{CaO}-\mathrm{NiMo}_{3} \mathrm{Al}_{2} \mathrm{O}_{3}$ & $44.0(0.82)$ & $2.3(0.52)$ \\
$5 \% \mathrm{CaO}-\mathrm{NiMo}_{2} \mathrm{Al}_{2} \mathrm{O}_{3}$ & $20.9(0.39)$ & $1.1(0.25)$ \\
$2 \% \mathrm{MgO}-\mathrm{NiMo}_{\mathrm{Al}_{2} \mathrm{O}_{3}}$ & $49.3(0.92)$ & $4.4(1.00)$ \\
$5 \% \mathrm{MgO}-\mathrm{NiMo} / \mathrm{Al}_{2} \mathrm{O}_{3}$ & $44.3(0.90)$ & $3.3(0.75)$ \\
\hline
\end{tabular}

${ }^{* 1}$ : Hydrogenation activity. Figures show yields of methyltetralins (\%) from 1-methylnaphthalene. Figures in parentheses show the relative activity to the catalyst without doping.

*2 : Hydrocracking activity. Figures show yields of benzene and toluene (\%) from diphenylmethane. Figures in parentheses show the relative activity to the catalyst without doping.

(1) $\mathrm{Mg}, \mathrm{Ca}$ いずれの修飾を行っても触媒上への炭素質たい 積量は減少するが, 液化油の脱窒素活性は低下する。

(2) $\mathrm{Mg}$ と $\mathrm{Ca}$ の比較では, ニッケル-モリブデン触媒-液化 油 $\mathrm{A}$ の場合を除き $\mathrm{Mg}$ 修飾触媒の方が活性低下の程度は小さ い。特に原料油が重質化すると, 両者の脱窒素活性の差は大き い。

(3) 修飾により起こる活性低下と炭素質たい積量減少の効果 を総合すると，原料が重質油の場合，特にへキサン不溶分を含 む場合に，ニッケルーモリブデン触媒への $\mathrm{Mg}$ 修飾が最も有効 であった。

\section{$3 \cdot 3$ アルカリ土類修飾触媒の性質と炭秦質のたい皘挙的}

アルカリ土類の修飾によるモリブデン，ニッケルーモリブデ ン担持触媒の基本活性（水素化および水素化分解活性）の変化 をモデルテスト反応によって評価した結果を Table 5 に示し た。3・1にも示したように, 両触媒系とも Ca による修飾を 行った場合, 水素化分解活性だけでなく水素化活性もほほ同様 な割合で低下しており，酸性質のみを選択的に制御することは 困難であることがわかる。 $\mathrm{Mg}$ による修飾でもほほ同様の傾向 がみとめられるが, 水素化分解活性の低下割合は比較的小さく, 特に $2 \% \mathrm{MgO}-\mathrm{Mo} / \mathrm{Al}_{2} \mathrm{O}_{3}$ では修飾により活性は向上している。 これは $\mathrm{Mg}$ 修飾により, 一部, $\mathrm{Mg}$ と Mo あるいは $\mathrm{Mg}$ と $\mathrm{Al}$ の複合酸化物が生成し, 硫化過程を経て水素化分解活性点と なったためと考えられる。液化油の水素化脱窒素活性は触媒の 


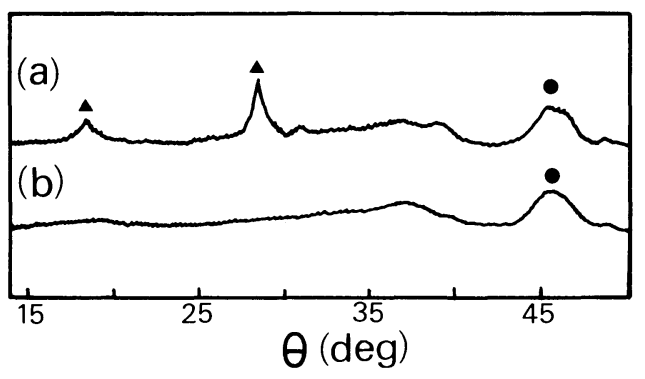

(a): $5 \% \mathrm{CaO}-\mathrm{Mo} / \mathrm{Al}_{2} \mathrm{O}_{3},\left(\right.$ b) $: 5 \% \mathrm{MgO}-\mathrm{Mo} / \mathrm{Al}_{2} \mathrm{O}_{3}$

A: $\mathrm{CaMoO}_{4}, \mathbf{O}: \gamma-\mathrm{Al}_{2} \mathrm{O}_{3}$

Fig. 1 X-ray Diffraction Patterns for $\mathrm{Ca}(\mathrm{Mg})$-Doped Catalysts

Table 6 Physical Properties of $\mathrm{Mg}(\mathrm{Ca})$-Doped Mo and $\mathrm{Ni}$-Mo Catalysts

\begin{tabular}{l|ccc}
\hline \multicolumn{1}{c|}{ Catalyst } & $\begin{array}{c}\text { Surface area } \\
\left(\mathrm{m}^{2} / \mathrm{g}\right)\end{array}$ & $\begin{array}{c}\text { Acidity } \\
\text { (mmol/ } \\
\text { g-cat })\end{array}$ & $\begin{array}{c}\text { (mmol/ } \\
\left.\text { m }^{2} \text {-cat }\right)\end{array}$ \\
\hline $\mathrm{Al}_{2} \mathrm{O}_{3}$ & 210 & 0.31 & $1.5 \times 10^{-3}$ \\
$\mathrm{Mo} / \mathrm{Al}_{2} \mathrm{O}_{3}$ & 208 & 0.23 & 1.1 \\
$2 \% \mathrm{CaO}-\mathrm{Mo} / \mathrm{Al}_{2} \mathrm{O}_{3}$ & 192 & 0.21 & 1.1 \\
$5 \% \mathrm{CaO}-\mathrm{Mo} / \mathrm{Al}_{2} \mathrm{O}_{3}$ & 173 & 0.08 & 0.5 \\
$2 \% \mathrm{MgO}-\mathrm{Mo} / \mathrm{Al}_{2} \mathrm{O}_{3}$ & 195 & 0.26 & 1.3 \\
$5 \% \mathrm{MgO}-\mathrm{Mo} / \mathrm{Al}_{2} \mathrm{O}_{3}$ & 177 & 0.24 & 1.4 \\
$\mathrm{Ni}-\mathrm{Mo} / \mathrm{Al}_{2} \mathrm{O}_{3}$ & 204 & 0.30 & 1.5 \\
$2 \% \mathrm{CaO}-\mathrm{NiMo}_{2} \mathrm{Al}_{2} \mathrm{O}_{3}$ & 184 & 0.19 & 1.0 \\
$5 \% \mathrm{CaO}-\mathrm{NiMo}_{\mathrm{Al}_{2}} \mathrm{O}_{3}$ & 166 & 0.17 & 1.0 \\
$2 \% \mathrm{MgO}-\mathrm{NiMo} / \mathrm{Al}_{2} \mathrm{O}_{3}$ & 188 & 0.25 & 1.3 \\
$5 \% \mathrm{MgO}-\mathrm{NiMo} / \mathrm{Al}_{2} \mathrm{O}_{3}$ & 178 & 0.25 & 1.4 \\
\hline
\end{tabular}

${ }^{*} 1$ : Determined by TPD method.

水素化, 水素化分解両活性に大きく依存することが知られてお $\eta^{12), 16), 17)}$ ，事実モデルテスト反応の結果と脱窒素活性の序列 はよく一致した傾向が得られた。

次に，上記触媒活性低下の原因を調べるために，各触媒の $\mathrm{X}$ 線回折パターンを測定した。Fig. 1 から明らかなように, $\mathrm{Ca}$ 修飾触媒では $\mathrm{CaMoO}_{4}$ の粒子が生成していることがわか る。 $\mathrm{CaMoO}_{4}$ の生成は, 分散度の低下による活性金属表面積 の低下, 構造変化による高活性 $\mathrm{MoS}_{2}$ 相の生成の抑制などを 引き起こすことから, 修飾触媒の活性低下の主原因と考えられ る。基本活性の低下の小さい $\mathrm{Mg}$ 修飾触媒では, $\gamma$-アルミナ に相当するブロードなピーク以外認められなかった（Fig. 1)。

Table 6 にはアルカリ土類修飾による触媒表面積, および 酸性質の変化を示した。いずれの修飾触媒でも, 表面積の減少 が認められており，アルカリ土類修飾によって細孔が閉そく， 狭さく化していることがわかる。また表面積の滅少割合は, $\mathrm{Ca}$ 修飾の場合の方が $\mathrm{Mg}$ 修飾の場合よりも著しく, 前記 X 線回折の測定結果と併せ考えると, 活性成分の凝集により細孔 が狭さく化したと推察される。酸量の変化に着目すると, Ca 修飾の場合, 絶対量, 単位表面積当たりの量ともに隇少してい るが, $\mathrm{Mg}$ 修飾の場合単位表面積当たりの酸量には大きな変化 は認められなかった。この結果は, 炭素質たい積の抑制には $\mathrm{Ca}$ 修飾の方が $\mathrm{Mg}$ 修飾より効果が大きいという結果 (Table 4）と一致している。一方, $\mathrm{Mg}$ 修飾触媒では酸量は変化して いないが, たい積炭素質量は隇少しており炭素質のたい積, コー

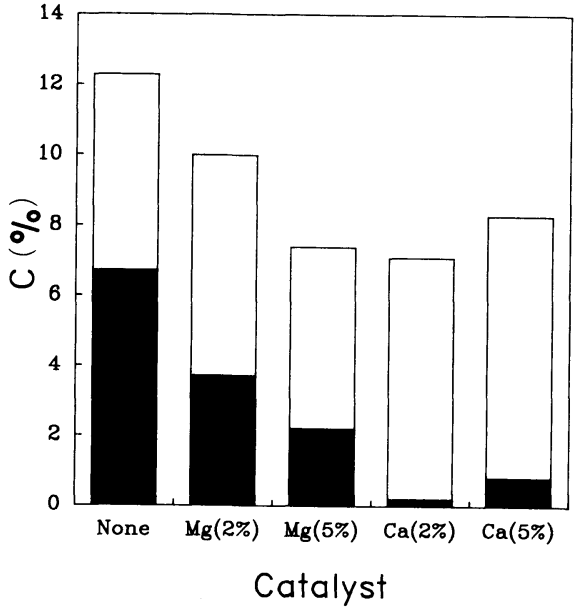

: Hexane insoluble and toluene soluble fraction. $\square$ : Toluene insoluble fraction.

Fig. 2 Carbonaceous Deposition on $\mathrm{Ca}(\mathrm{Mg})$-Doped Catalysts

ク化の進行は酸点の量のみでなく酸強度, 酸の種類 (ルイス酸, ブレンステッド酸）など酸点の性質にも深く関係することを示 唆している。

$5 \% \mathrm{Ca}$ 修飾触媒では, 酸量は減少しているにもかかわらず, 液化油 $\mathrm{C}$ の水素化処理中の炭素質たい積の抑制効果は小さい (Tables 3, 4)。また，たい積炭素質のコーク化の進行状況を 調べた結果，Ca 修飾触媒ではトルエン不溶分の割合が多く， たい積炭素質が重質化している傾向が認められた（Fig. 2)。 これらの事実は, $\mathrm{Ca}$ 修飾触媒では酸量が少なく極性成分の強 い吸着は起こりにくいものの，一度吸着された成分は容易に脱 離せず重質化する傾向にあることを示唆している。前述したモ デルテスト反応の結果（Table 5) を考慮すれば, 水素化活性 の高い触媒上では吸着した極性成分は速やかに水素化され脱離 するのに対して，活性の低い $5 \% \mathrm{Ca}$ 修飾触媒ではたい積炭素 質のコーク化が進行したものと考えられる。触媒の水素化活性 と触媒上への炭素質析出挙動に関しては, 水素化活性点がコー ク析出の核になりやすいとする報告 ${ }^{18)}$ と, 逆に水素化活性が コーク化を抑制するとする報告 ${ }^{19)}$ とがある。これらの報告は, 何れも比較的水素圧力の低い需囲気下でのモデル物質の水素 化，水素化分解反応であり，本研究のようにへキサン不溶分を 含む場合とは状況が異なる。しかしながら, 高圧水素化では平 衡が水素化側によること，また重質原料は水素不足であり水素 化が進行しないと重合しゃすいことなどを考慮すれば，上記モ デル実験と比べて, 触媒の水素化活性がコーク質の析出抑制に 関して有利に作用すると考えられる。

炭素質による触媒活性の低下を抑制するに当たっては，触媒 上への炭素質たい積量を隇少させると同時にたい積した炭素質 のコーク化を抑えることが不可欠である。反応初期段階での炭 素質のたい積は酸性質を制御することによってある程度可能で あることがわかった。一方，原料中にへキサン不溶分のような 重質成分が含まれる場合, 炭素質のコーク化を抑制するには, 前述のように, 触媒に高い水素化活性が要求されることが示さ れた。従って，炭素質による触媒活性低下を総合的に抑制する 
ためには，酸性質を制御することにより触媒表面への極性物質 のたい積を抑制すると同時に，たい積炭素質のコーク化を防ぐ ために高い水素化活性を賦与することが必要と考えられる。ま た, 液化油の水素化処理性能についても, 水素化活性の高いニッ ケルーモリブデン触媒の方がモリブデン触媒よりアルカリ土類 修飾による脱窒素活性の低下の程度は小さかった（Tables 3, 4)。これらの事実は, 液化油水素化処理触媒では, 高度の水 素化分解活性機能を有するだけでは触媒寿命, 初期活性いずれ の面からも不十分であり，水素化分解活性と水素化活性のバラ ンスが不叮欠であることを示唆している。

\section{4. 結}

アルカリ土類修飾により触媒酸性質を制御し，炭素質たい積 の抑制を試みた結果，以下のようなことがわかった。

(1) アルカリ土類修飾によって触媒の酸性質は制御，改質さ れ, 液化油水素化処理反応中の炭素質たい積は抑制される。し かしながら, 修飾によって触媒の水素化, 水素化分解活性は低 下し, 液化油脱窒素活性も低下寸る。

(2) 修飾法としては，活性成分を担持，焼成後にアルカリ土 類金属を含浸担持する方法が最も触媒活性低下は小さかった。 また，触媒活性低下の原因は活性成分（主としてモリブデン） を含む複酸化物粒子の成長, および活性金属化学結合状態の変 化による触媒有効表面積の減少と考えられる。

(3) $\mathrm{Ca}$ 修飾と $\mathrm{Mg}$ 修飾を比較した場合， Ca 修飾の方が酸 性質制御の効果は大きいが, 活性低下は $\mathrm{Mg}$ 修飾の方が小さ い。特に, 原料油が重質化した場合, $\mathrm{Mg}$ 修飾触媒では, 炭素 質たい積が抑制され，かつ活性低下が小さい。

(4) 炭素質たい積による触媒活性低下を長期的に抑制するた めには触媒酸性質の制御と同時に, 触媒に高い水素化活性を賦 与することが必要と考えられる。従って,アルカリ土類修飾な どの酸性質制御を行うにあたっては，特に水素化活性の維持, あるいは向上に留意する必要がある。

以上のように, アルカリ土類修飾では, 酸性質の制御はある 程度可能なものの, 活性成分とアルカリ土類金属との複酸化物 の成長による活性低下の問題があることがわかった。今後, 修 飾方法の改良などによって, 触媒活性の低下を防止する対策を 確立する必要があると考えられる。一方, 本研究の結果からも 示唆されるように, アルカリ土類金属は, 本質的には触媒被毒 物質であり，触媒活性をある程度低下させることは防ぎ得ない であろう。従って, 高い水素化処理活性（脱窒素, 水素化分解
等）を有しかつ炭素質による活性低下の少ない触媒の開発に当 たっては,アルミナ以外の担体種を用いるなど新しい方法の検 討も必要であろう。

\section{References}

1) Ocampo, A., Schrodt, J. T., Kovach, S. M., Ind. Eng. Chem., Prod. Res. Dev., 17, 56 (1978).

2) Polinski, L. M., Stiegel, G. J., Tischer, R. J., “1980 Status Review/Hydroliquefaction of Coal with Supported Catalysts", DOE/PETC/TR-81/2 (1981).

3) Thakur, D. S., Thomas, M. G., Ind. Eng. Chem., Prod. Res. Dev., 23, 349 (1984).

4) Thakur, D. S., Thomas, M. G., Applied Catalysis, 15, 197 (1985).

5) Weller, S. W., "Coal Liquefaction with Molybdenum Catalysts", in Proc. 4th Int. Conf. on the Chemistry and Uses of Molybdenum, 1982 Climax, pp. 179.

6) Cable, T. L., Massoth, F. E., Fuel Processing Technol., 4, 265 (1981)

7) Cable, T. L., Massoth, F. E., Thomas, M. G., Fuel Processing Technol., 10, 105 (1985).

8) Thakhur, D. S., Thomas, M. G., Applied Catal., 6, 283 (1983).

9) Stiegel, G. J., Tiscer, R. E., Polinski, L. M., Ind. Eng. Chem., Prod. Res. Dev., 22, 411 (1983).

10) Sanders, J. V., Spink, J. A., Pollack, S. S., Applied Catal., 5, 65 (1983).

11) Furimsky, E., Fuel Processing Technol., 6, 1 (1982).

12) Togari, O., Ono, T., Nakamura, M., Sekiyu Gakkaishi, 2, 336 (1979)

13) Niwa, M., Shokubai, 28, 35 (1986).

14) Shimada, H., Sato, T., Kurita, M., Yoshimura, Y., Nishijima, A., Sekiyu Gakkaishi, 27, 122 (1984).

15) Yoshimura, Y., Hayamizu, K., Sato, T., Shimada, H., Nishijima, A., Fuel Processing Technol., 16, 55 (1987).

16) Satterfield, C. N., Cochetto, J. F., Ind. Eng. Chem. Process Des. Dev., 20, 53 (1981).

17) Bhinde, M. V., Shih, S., Zawadsky, R., Katzer, J. R., Kwart, H., "Hydrodenitrogenation Over MolybdenumContaining Catalysts", in Proc. 3rd Int. Conf. on the Chemistry and Uses of Molybdenum, 1979 Climax, pp 184.

18) Scaroni, A. W., Jenkins, R. G., Walker, Jr. P. L., Applied Catal., 14, 173 (1985).

19) Laine, J., Brito, J., Severino, F., Applied Catal., 15, 333 (1985). 
Summary

\title{
Suppression of Coke Formation on Molybdenum Coal Liquid Hydrotreating Catalysts by Alkali Earth Doping
}

\author{
Hiromichi Shimada $^{\dagger 1)}$, Toshio Sato ${ }^{\dagger 1)}$, Yuji Yoshimura ${ }^{\dagger 1}$, Akio Nishijima ${ }^{\dagger 1}$, \\ Masahide Matsuda $^{\dagger 2)}$, Takeo Konakahara ${ }^{\dagger 2}$, and Kenji $\mathrm{SatO}^{\dagger 2)}$ \\ †1) National Chemical Laboratory for Industry, \\ Tsukuba-shi, Ibaraki 305 \\ †2) Science University of Tokyo, Yamazaki \\ Noda-shi, Chiba 278
}

\begin{abstract}
Suppression of coke formation on supported catalysts is one of the most important approaches to lowering the catalyst deactivation rate. In the present study, Mo and Ni-Mo supported catalysts were doped with alkali earth metal oxides in order to decrease the amount of carbonaceous deposition on the catalyst.

Doping with alkali earth metal oxides was carried out by three different methods (Table 2). Comparing the fundamental activities of the doped catalysts, method $\mathrm{C}$, which gives the highest activities among the three, was selected for preparing the catalysts in the experiment described below. While doping reduces hydrodenitrogenation (HDN) activities of both Mo (Table 3) and Ni-Mo (Table 4) catalysts, the amounts of carbonaceous deposition on the catalysts decrease. Doping with $\mathrm{Ca}$, as compared to that with $\mathrm{Mg}$, has a greater effect on both decreasing the deposition and reducing the HDN activity. The doping effects explained above strongly depend on the properties of the feedstocks used (Table 1). In the hydrotreating of Feed A (Middle distillate), the doping does not lower the amount of carbonaceous deposition, but reduces the HDN activity of the catalyst (Table 3). While, in the case of hydrotreating Feed $\mathrm{C}$ containing asphaltene, the Ni-Mo catalyst doped with $\mathrm{Mg}$ gives almost the same HDN activity, but a smaller amount of carbonaceous deposition on the catalyst relative to the undoped $\mathrm{Ni}$ Mo catalyst (Table 4). Ni-Mo catalysts are more favorably affected by alkali earth doping than are Mo catalysts, especially when heavy feedstocks are used. In particular HDN activity is only slightly decreased while
\end{abstract}

carbonaceous deposits are significantly minimized.

Results from several different characterizations of doped catalysts are consistent with those obtained in hydrotreating coal-derived liquids. Doping with $\mathrm{Ca}$, as compared to doping with $\mathrm{Mg}$, is more effective for decreasing the acid content of the catalyst, but reduces the surface area significantly (Table 6). An X-ray diffraction study of catalysts doped with $\mathrm{Ca}$ indicates the formation of $\mathrm{CaMoO}_{4}$ particles which reduces the number of active sites on molybdenum sulfide species (Fig. 1). These phenomena decrease the fundamental activities (hydrogenation (HY) and hydrocracking (HC)) of the catalysts (Table 5), which lower the HDN activity during hydrotreating of coal-derived liquids. Solvent fractionation of the carbonaceous deposition on the catalysts shows that coking of the deposited materials occurs significantly on catalysts doped with Ca which have low hydrogenation (HY) activity (Fig. 2). This indicates that HY activity plays an important role in preventing coke formation on the catalyst.

The important findings of the present paper are summarized below. Doping with alkali earth metal modifies the acid properties of the catalyst and decreases the carbonaceous deposition. The doping, however, reduces the fundamental activities of the catalyst, which results lower HDN activity during hydrotreating of coal-derived liquids. In order to minimize the catalyst deactivation by coking, not only is it important to control the acidity of the catalyst, it is essential to have high HY activity.

\section{Keywords}

Alkali earth metal, Catalyst modification, Coal liquid, Coke deposition, Hydrotreating, Molybdenum catalyst 